\title{
Development of Teachers' Empowerment Scale: A Validity and Reliability Study
}

\section{Yeliz Ozkan Hidiroglu (D) 1,*, Abdurrahman Tanriogen (D)2}

\author{
${ }^{1}$ Ministry of National Education, Denizli, Turkey \\ ${ }^{2}$ Department of Educational Science, Faculty of Education, Pamukkale University, Denizli, Turkey
}

\author{
ARTICLE HISTORY \\ Received: Feb. 24, 2020 \\ Revised: Oct. 21, 2020 \\ Accepted: Dec. 04, 2020

\section{KEYWORDS} \\ Teacher empowerment, \\ Scale development, \\ Exploratory factor \\ analyzes, \\ Confirmatory factor \\ analyzes, \\ Teacher
}

\begin{abstract}
In this research, it is aimed to develop a measurement tool to determine teachers' perceptions about empowerment in a valid and reliable way. The research data were collected from two different teacher groups of 700 people $(405+295$ teachers) who worked in the fall semester of the 2019-2020 academic year. For the content and appearance validity of the scale, seven experts were consulted in the study. Exploratory (EFA) and Confirmatory (CFA) factor analyzes were performed for the construct validity of the scale. As a result of the EFA, a structure with 37 items and 4 factors explaining $69.53 \%$ of the total variance was revealed. These factors have been named as "trust", "status", "professional development" and "cooperation". Findings from CFA showed that the 37-item and four-factor structure related to teacher empowerment scale had adequate fit indices. The reliability of the measurements obtained from the teacher empowerment scale and dimensions were examined by Cronbach alpha and omega reliability method and it was determined that the calculated reliability coefficients were within the acceptable limits. Item-total correlations were examined to determine item discrimination. Findings from the item analysis showed that all of the items in the scale are distinctive. Based on these findings, it can be said that the Teacher Empowerment Scale is a measurement tool that produces valid and reliable measurements and can be used to determine teachers' perceptions about empowerment.
\end{abstract}

\section{INTRODUCTION}

Teachers play an important role in increasing student achievement and providing conceptual learning by designing and implementing a quality learning process in educational institutions. One of the key elements in most educational reforms is teachers (Fandino, 2010). The quality of a school is based on the quality of teachers working in that institution (Acquaah, 2004). Empowerment of teachers is closely related to the leadership of school administrators and the opportunities they provide to participate in the decision-making (Addi-Raccah, 2009). Because school administrators are the people who facilitate the empowerment of students and teachers in school (Morales-Thomas, 2015). 
The concept of teacher empowerment is handled by different researchers with different definitions. According to Sharma (2014), empowering teachers is supporting teachers to become a shaper by supporting their experiences, decision-making authorities and powers, making them feel that they have a real key person in school practices and conditions. Bogler and Somech (2004) define the empowerment of teachers as a process in which teachers deal with their own development and have the ability to solve their own problems. According to Rappaport (1985), empowering teachers is controling their own personality, cognition, and motivation. Zimmerman (2000) argues that empowering teachers is both a process and a result.

The results of empirical research have shown that teacher empowerment generally plays a positive role in educational settings. For example, researchers have found that teacher empowerment increases teachers' job satisfaction (Rice \& Schneider, 1994; Rinehart \& Short, 1994), professional commitment and organizational citizenship behaviors (Bogler \& Somech, 2004), organizational commitment (Somech, 2005), professionalism and self-confidence (Dee, Henkin, \& Duemer, 2003) but decreases teachers' professional burnout (Dee et al. 2003). Therefore, it is thought that empowering teachers and awakening their sense of empowerment can lead to many positive organizational behaviors and eventually they can play an important role in teachers' organizational success and stable work (Bogler \& Somech, 2004).

The concept of teacher empowerment is handled in different dimensions by different researchers. Wilson and Coolican (1996) consider teacher empowerment in two dimensions as external and internal power. Short and Rinehart (1992) discuss teacher empowerment in six dimensions: "decision making", "professional development", "status", "self-efficacy", "autonomy and influence". Yin, Jin and Lee (2009) consider teacher empowerment in three dimensions as "professional development at school", "participation in decision-making" and "effect of teachers' work on other colleagues". Al-Yaseen and Al-Musaileem (2015) reviewed teacher empowerment literature (Lichenstein, McLuaghlin \& Knudsen, 1991; Lieberman \& Miller, 1990; Lightfoot, 1986; Maeroff, 1988; Morris \& Nunnery, 1993; Short, 1991; Sizer, 1992; Sprague, 1992) and identified 13 dimensions of teacher empowerment by scanning. These are; (1) accountability, (2) authority, (3) curriculum planning, (4) cooperation, (5) decision making, (6) impact, (7) professional development, (8) professional knowledge, (9) responsibility, (10) self-efficacy, (11) self-esteem, (12) status, and (13) new teacher training. Altınkurt, Türkkaş Anasız and Ekinci (2016) state that the concept of teacher empowerment includes two main dimensions as structural empowerment, which focuses on managerial processes and the regulation of processes, and psychological empowerment that guides teachers' perceptions. In the international literature, it has been determined that the scale of Kanter (1993) for structural empowerment and Spreitzer (1995) for psychological empowerment are frequently used. Kanter (1993) deals with structural empowerment as information, opportunity, resources, support, power and informal power dimensions and explains these dimensions. Spreitzer (1995) on the other hand, discusses and explains psychological empowerment in terms of meaning, effect, competence and autonomy.

When the literature is analyzed, it is seen that there is no common consensus in definitions and classifications about teacher empowerment. It is seen that the most widely used data collection instrument related to the subject is Short and Rinehart's (1992) teacher empowerment scale. The original name of the scale of Short and Rinehart (1992) is "School Participants Empowerment Scale". While this scale is considered as "Teacher Empowerment Scale" in some studies (Ökmen, 2018; Somech, 2005), in some studies it is considered as "School Participants Empowerment Scale” (Bogler, 2005; Bogler \& Nir, 2012; Jiang, Li, Wang, \& Li, 2019; Lintner, 2008; Sharp, 2009; Squire-Kelly, 2012; Veisi, Azizifar, Gowhary \& Jamalinesari, 2015; Watts, 2009). In addition, the scale of Short and Rinehart (1992) was carried out on the Israeli sample in 1992. The "Teacher Empowerment Scale" developed by Yin, Jin and Lee (2009) was 
developed in line with the reform of the curriculum in China and teachers in China were used as a sample. "Teacher Empowerment Scale", which is prepared and applied directly for teachers, is not encountered. Apart from this, studies that deal with structural empowerment scales and psychological empowerment scales for teachers are discussed separately. There are two common empowerment scales in the literature: structural empowerment and psychological empowerment. Structural empowerment consists of six dimensions such as "opportunity", "knowledge", "resources", "support", "formal power" and "informal power". Psychological empowerment consists of four dimensions such as "meaning", "effect", "competence" and "autonomy". The purpose of this research is to make these two different scale types into a single scale. With this research, it is aimed to develop the "Teacher Empowerment Scale" prepared for the teachers directly by the researchers, to make validity and reliability calculations and to present a valid and reliable Teacher Empowerment Scale. This scale can contribute to the development of new ideas on determining the empowerment levels of teachers, revealing the current situation for the position of teachers, and taking measures for possible improvements. In addition, the interactions between teacher empowerment and various variables can be examine. It is thought that this scale will be important in determining how strong the teachers feel, and will contribute to the literature as it is an original scale for teacher empowerment.

\section{METHOD}

\subsection{The Model of Research}

This study is a scale development study. In the research conducted on the screening model, information about the sample group, measurement tool and techniques used in data analysis are given below.

\subsection{Population and Sampling}

\subsubsection{Sampling Group 1}

In the measuring instrument development process teachers who work in different branches in different regions of Turkey during 2019-2020 academic year were included in the sample. The study was first conducted with 405 teachers. In the research, extreme values were removed and the study was advanced over 368 teachers. An exploratory analysis was conducted by using this sample. In order to look at the multivariate normal distribution, "Mahalanobis Distance Coefficient" was examined. According to $62(d f) p$ values less than .001 are eliminated. The distribution of the teachers in the sampling group is given in Table 1.

\subsubsection{Sampling Group 2}

In order to conduct Confirmatory Factor Analysis the 37 items scale was applied again to volunteer teachers actively working in different branches during 2019-2020 academic year. In the second phase 295 teachers participated in the research. After removing outliers the data were subjected to Confirmatory Factor Analysis over 266 teachers. The demographic characteristics of the teachers in the second participant group are shown in Table 2. 
Table 1. Distribution of Teachers according to Demographic Characteristics

\begin{tabular}{|c|c|c|c|}
\hline \multicolumn{2}{|c|}{ Variables } & $n$ & $\%$ \\
\hline \multirow{3}{*}{ Gender } & Female & 255 & 69.3 \\
\hline & Male & 113 & 30.7 \\
\hline & Total & 368 & 100 \\
\hline \multirow{3}{*}{ School Type } & State & 342 & 92.9 \\
\hline & Private & 26 & 7.1 \\
\hline & Total & 368 & 100 \\
\hline \multirow{5}{*}{ Age } & 20-30 ages & 66 & 18 \\
\hline & $31-40$ ages & 188 & 51 \\
\hline & $41-50$ ages & 92 & 25 \\
\hline & 51 age and over & 22 & 6 \\
\hline & Total & 368 & 100 \\
\hline \multirow{9}{*}{ Branch } & Pre School & 12 & 3.3 \\
\hline & Art & 74 & 20.1 \\
\hline & Science-Math & 75 & 20.4 \\
\hline & Classroom & 60 & 16.3 \\
\hline & Social & 49 & 13.3 \\
\hline & Sport & 24 & 6.5 \\
\hline & Foreign Language & 50 & 13.6 \\
\hline & Others & 24 & 6.5 \\
\hline & Total & 368 & 100 \\
\hline \multirow{8}{*}{ Region } & Mediterranian & 38 & 10.3 \\
\hline & East Anatolia & 28 & 7.6 \\
\hline & Aegean & 92 & 25 \\
\hline & South East Anatolia & 26 & 7.1 \\
\hline & Central Anatolia & 64 & 17.4 \\
\hline & Black Sea & 32 & 8.7 \\
\hline & Marmara Region & 88 & 23.9 \\
\hline & Total & 368 & 100 \\
\hline \multirow{6}{*}{ Seniority } & $0-5$ years & 59 & 16,1 \\
\hline & 6-10 years & 82 & 22.3 \\
\hline & $11-15$ years & 91 & 24.7 \\
\hline & 16-20 years & 56 & 15.2 \\
\hline & 21 years and over & 80 & 21.7 \\
\hline & Total & 368 & 100 \\
\hline \multirow{5}{*}{$\begin{array}{c}\text { Working duration in the } \\
\text { same school }\end{array}$} & $0-2$ years & 128 & 34.8 \\
\hline & $3-5$ years & 124 & 33.7 \\
\hline & $6-8$ years & 67 & 18.2 \\
\hline & 9 years and over & 49 & 13.3 \\
\hline & Total & 368 & 100 \\
\hline \multirow{5}{*}{ Educational Status } & Two Years Degree & 8 & 2.2 \\
\hline & Bachelor of Science & 276 & 75 \\
\hline & Master's Degree & 78 & 21.2 \\
\hline & PhD Degree & 6 & 1.6 \\
\hline & Total & 368 & 100 \\
\hline
\end{tabular}


Tablo 2. Distribution of Teachers according to Demographic Characteristics

\begin{tabular}{|c|c|c|c|}
\hline \multicolumn{2}{|c|}{ Variables } & $n$ & $\%$ \\
\hline \multirow{3}{*}{ Gender } & Female & 140 & 52.6 \\
\hline & Male & 126 & 47.4 \\
\hline & Total & 266 & 100 \\
\hline \multirow{3}{*}{ School Type } & State & 242 & 90.9 \\
\hline & Private & 24 & 9.1 \\
\hline & Total & 266 & 100 \\
\hline \multirow{5}{*}{ Age } & 20-30 ages & 57 & 21.4 \\
\hline & 31-40 ages & 148 & 55.6 \\
\hline & $41-50$ ages & 43 & 16.2 \\
\hline & 51 age and over & 18 & 6.8 \\
\hline & Total & 266 & 100 \\
\hline \multirow{9}{*}{ Branch } & Science-Math & 73 & 27.4 \\
\hline & Social & 83 & 31.2 \\
\hline & Foreign Language & 24 & 9.1 \\
\hline & Art & 20 & 7.5 \\
\hline & Sport & 17 & 6.4 \\
\hline & Classroom & 30 & 11.3 \\
\hline & Pre School & 7 & 2.6 \\
\hline & Others & 12 & 4.5 \\
\hline & Total & 266 & 100 \\
\hline \multirow{8}{*}{ Region } & Mediterranian & 19 & 7.1 \\
\hline & East Anatolia & 12 & 4.5 \\
\hline & Aegean & 145 & 54.5 \\
\hline & South East Anatolia & 14 & 5.3 \\
\hline & Central Anatolia & 31 & 11.7 \\
\hline & Black Sea & 21 & 7.8 \\
\hline & Marmara Region & 24 & 9.1 \\
\hline & Total & 266 & 100 \\
\hline \multirow{6}{*}{ Seniority } & $0-5$ years & 48 & 18,1 \\
\hline & 6-10 years & 77 & 28.9 \\
\hline & $11-15$ years & 66 & 24.8 \\
\hline & $16-20$ years & 31 & 11.7 \\
\hline & 21 years and over & 44 & 16.5 \\
\hline & Total & 266 & 100 \\
\hline \multirow{5}{*}{$\begin{array}{l}\text { Working duration in the } \\
\text { same school }\end{array}$} & $0-2$ years & 90 & 33.8 \\
\hline & $3-5$ years & 105 & 39.5 \\
\hline & $6-8$ years & 46 & 17.3 \\
\hline & 9 years and over & 25 & 9.4 \\
\hline & Total & 266 & 100 \\
\hline \multirow{5}{*}{ Educational Status } & Two Years Degree & 4 & 1.5 \\
\hline & Bachelor of Science & 206 & 77.5 \\
\hline & Master's Degree & 52 & 19.5 \\
\hline & PhD Degree & 4 & 1.5 \\
\hline & Total & 266 & 100 \\
\hline
\end{tabular}




\subsection{Data Collection Instrument and Data Collection}

To develop a scale for teacher empowerment, a literature review was conducted on the subject. In accordance with the related literature, individual interviews were held with 32 teachers. Individual interviews play an important role in clarifying the dimensions and deciding the scale items (DeVellis, 2003). Teachers participating in the research were informed in detail about teacher empowerment and teachers were asked to answer the following interview questions accordingly:

"What do you think is power?", "How do you define power?", "Who has power in your school? Please explain your answers with their reasons.", "What do you think empowerment means?", "Who can get you empowered?", "In what kind of environments do you feel empowered as a teacher?"; "What kind of environment does your manager provide you feel empowered?"; "What manager behaviors make you feel empowered as a teacher?"; "What kind of training would you like to make you feel empowered as a teacher? sounding questions were included to find more detailed answers to these interview questions.

The 64 pages written response papers collected from 32 teachers by the researchers were subjected to content analysis. In content analysis, firstly, two researchers created codes in line with the theoretical framework, and then similar codes were grouped and categories were created. In the process of data analysis, these steps proposed by Y1ldırım and Şimşek (2005) were followed: naming, coding and extraction, category development, ensuring validity and reliability and reporting.

After this step, a pool of 60 items was created by combining the relevant literature and teacher statements. This items pool was shaped in line with the views of two experts with PhD degrees in educational sciences. These items and the dimensions related to these items were presented to expert opinions in order to ensure scope and appearance validity and necessary arrangements were made in line with the opinions of seven experts who gave feedbacks. Accordingly, arrangements were made in the content and statements of the items and two more items were added. Finally, in order to prevent comprehension and language problems, the items were sent to four Turkish teachers and related corrections were made. Initially, the scale composed of 62 items were applied to 405 teachers who are working in different regions of Turkey. Outliers were discarded from the applied scale and the study was carried out with data gathered from 368 teachers. Kass and Tinsley (1979) state that at least 300 participant should be reached totally. According to Cattell (1978) 200 participants are acceptable and 500 participants are considered to be a very good number in factor analysis studies. Tabachnick and Field (2000) state that in order to make a healthy analysis, the sample should be at least five times of the items in the scale.

\subsection{Data Analysis}

The construct validity of the Teacher Empowerment Scale was studied. Item total correlation was analyzed as item statistics. Exploratory Factor Analysis (EFA) and Confirmatory Factor Analysis (CFA) were performed for construct validity. Cronbach Alpha $(\alpha)$ coefficient was calculated for the internal consistency reliability of the scale. Item total correlations were examined for item discriminations. For EFA, Cronbach Alpha and item discriminations, IBM SPSS Statistics 20.0 and Lisrel 8.7 for CFA were used.

The KMO coefficient and Barlett test result were calculated in order to determine the suitability of the data to factor analysis. The normality test of the dimensions of the scale and the entire scale was performed. The variances explained by the dimensions in the scale and the total explained variances were calculated. Screen plot graph was drawn using Jamovi program. The factors formed as a result of the exploratory factor analysis, items in the factors and factor loading distributions are included. Items with factor loadings below .50 were removed from the 
scale. The structure revealed by exploratory factor analysis was tested by confirmatory factor analysis. Afterwards, confirmatory factor analysis values and suitability were examined. A second-level confirmatory factor analysis was conducted in order to show that the dimensions of "professional development", "trust", "status" and "cooperation" obtained by the first-level confirmatory factor analysis of the teacher empowerment scale together represent the "teacher empowerment" variable as an upper level concept.

As a result of the second level CFA, the factorial model of the scale and standardized coefficients regarding the factor-item relationship were determined. In order to provide item analysis of the scale, item-total correlations were examined and item discrimination indixes were examined. In order to determine the reliability of the scale, Cronbach Alpha and McDonald's Omega $(\omega)$ values for the dimensions of the scale and the whole scale were calculated. Discriminant validity and convergent validity values were calculated.

\section{RESULT / FINDINGS}

In this section, the validity and reliability features of the "Teacher Empowerment Scale", which was obtained as a result of the data analysis obtained from the sample group, were emphasized.

\subsection{Findings Related to Validity}

\subsubsection{Findings Related to Exploratory Factor Analysis}

It is difficult to fully model the multivariate normal distribution for real life continuous variables (Abbott, 2011). Therefore, in multivariate analysis, it is recommended to perform univariate and multivariate extreme value examinations and then normalize the distributions with the same 'data transformations' at each variable level (Demir, Saatçioğlu \& İmrol, 2016). In order to look at the multivariate normal distribution, "Mahalanobis Distance Coefficient" was examined. According to $62 d f, p$ values less than .001 are eliminated.

Factor analysis was performed to determine the construct validity of the scale and to determine and dimension the factor loadings of the items. Factor analysis is defined as the process of revealing new concepts (variables) called a factorization or common factorsor obtaining operational definitions of concepts using factor loading values of items (Çokluk, Şekercioğlu \& Büyüköztürk, 2016). Factorization and rotation techniques are the concepts to be considered together in factor analysis (Tabachnick \& Fidel, 2000). Factor analysis was performed using principal axis factoring and varimax rotation. Here, varimax rotation was preferred in order to obtain a more generalizable factor structure rather than compatibility with the data (Şencan, 2005). In order to determine the suitability of the data for factor analysis, the Kaiser-MeyerOlkin (KMO) coefficient and the Barlett Sphericity test were calculated (see Table 3). KMO value .96 and Bartlett test result $\left(\chi^{2}=12339.121 ; p=.000\right)$ were found to be significant.

Table 3. Teacher Empowerment Scale KMO and Bartlett's Test Statistics

\begin{tabular}{|c|c|c|}
\hline Kaiser-Meyer-Olkin Me & Suitability & .960 \\
\hline \multirow{3}{*}{ Barlett Sphericity Test } & Chi-Square Value & 12339.121 \\
\hline & $d f$ & 666 \\
\hline & $p$ & .000 \\
\hline
\end{tabular}

The skewness and kurtosis values of this are taken into consideration. According to Karagöz (2016) and Darren and Mallery (2016), the skewness and kurtosis values should be between -2 and +2 for the data to show normal distribution. In this study, skewness and kurtosis values for four factors and the entire scale are given in Table 4. 
Table 4. Skewness and Kurtosis Values Regarding Teacher Empowerment Scale and Dimensions

\begin{tabular}{cccc}
\hline & Skewness & Kurtosis & Normality \\
\hline Professional Development & -1.013 & 1.009 & Normal Distribution \\
Trust & -.967 & 1.049 & Normal Distribution \\
Status & -.024 & -.498 & Normal Distribution \\
Cooperation & -.733 & 1.043 & Normal Distribution \\
\hline Teacher Empowerment & -.735 & 1.014 & Normal Distribution \\
\hline
\end{tabular}

In the scale with 62 items which item-total correlation values below .50 and overlapping items were eliminated. The final scale consists of 37 items and four dimensions. It is a 5-point Likert type (Strongly Agree, Agree, Partially Agree, Disagree, Strongly Disagree). In Exploratory Factor Analysis, the most frequently used technique regarding the adequacy of the sample size is the sampling adequacy measurement technique of Kaiser-Meyer-Olkin (KMO). Hutcheson and Sofroniou (1999) state that the KMO value being higher than .9 indicates an excellent sample size. In this study, KMO value was calculated as .96. Therefore, it can be said that the sample size is excellent. Although the number of people in the sample is very important for factor analysis, it is known that there are many different opinions in the literature about the number. According to Tabachnick and Fidell (2000), the sample should consist of at least 300 people. Comrey and Lee (1992) argue that 100 people can be considered "few", 200 people can be considered "okay", 300 can be considered "suitable", 500 are considered "very suitable" and over 1000 can be considered "perfect". It can be said that as the sample grows, the power of the analysis will increase and the errors will decrease (Yurdabakan \& Çüm, 2017). Table 5 presents the variances explained by the dimensions in the scale and the total explained variances.

Table 5. Total Variance Table

\begin{tabular}{|c|c|c|c|c|c|c|}
\hline \multicolumn{4}{|c|}{ Initial Eigenvalues } & \multicolumn{3}{|c|}{ Factor Loadings Total Squares } \\
\hline $\begin{array}{c}1 \\
0 \\
0 \\
0 \\
0\end{array}$ & Total & $\begin{array}{c}\text { Explained } \\
\text { Variance (\%) }\end{array}$ & Total Variance (\%) & Total & $\begin{array}{l}\text { Explained } \\
\text { Variance }\end{array}$ & $\begin{array}{c}\text { Total Explained } \\
\text { Variance (\%) }\end{array}$ \\
\hline 1 & 16.864 & $\% 45.577$ & 45.577 & 7.718 & $\% 20.860$ & 20.860 \\
\hline 2 & 3.659 & $\% 9.889$ & 55.466 & 7.529 & $\% 20.347$ & 41.208 \\
\hline 3 & 3.099 & $\% 8.377$ & 63.843 & 5.181 & $\% 14.004$ & 55.211 \\
\hline 4 & 2.102 & $\% 5.682$ & 69.525 & 3.963 & $\% 10.710$ & 65.921 \\
\hline
\end{tabular}

According to Table 5, eigenvalues of scale dimensions are 16,864 for factor 1, 3.659 for factor $2,3.099$ for factor 3 , and 2.102 for factor 4 . The variance explained by the first dimension is $20.860 \%$, the variance explained by the second dimension is $20.347 \%$, the variance explained by the third dimension is $14.004 \%$ and the variance explained by the fourth dimension is $10.710 \%$. The scale explains $65.921 \%$ of the total variance and has a four-dimensional structure with $2 \%$ eigenvalue and $17 \%$ variance. Henson and Roberts (2006) stated that the variance rate announced in the scale studies should provide a value of $52 \%$ and above. In addition, when the Screen Plot graph is examined, the graph has become horizontal after the fourth vertical line and it is concluded that the scale is four-dimensional (see Figure 1). Screen plot chart was drawn from the Exploratory Factor Analysis menu of Jamovi program. In the Additional Output section of the analysis, options such as Screen plot, and Model fit measures to obtain fit indices similar to interdimensional correlation or structural equation modeling applications are presented (Şahin \& Aybek, 2019).

Parallel analysis was used to decide the number of dimensions. The screen plot, is a graphing method to summary the results of parallel analysis. According to the Screen Plot chart, the items in the scale are collected under 4 factors. These factors are determined as "professional 
development", "trust", "status" and "cooperation" in line with the theoretical framework. Table 6 presents the items and factor loadings under these factors.

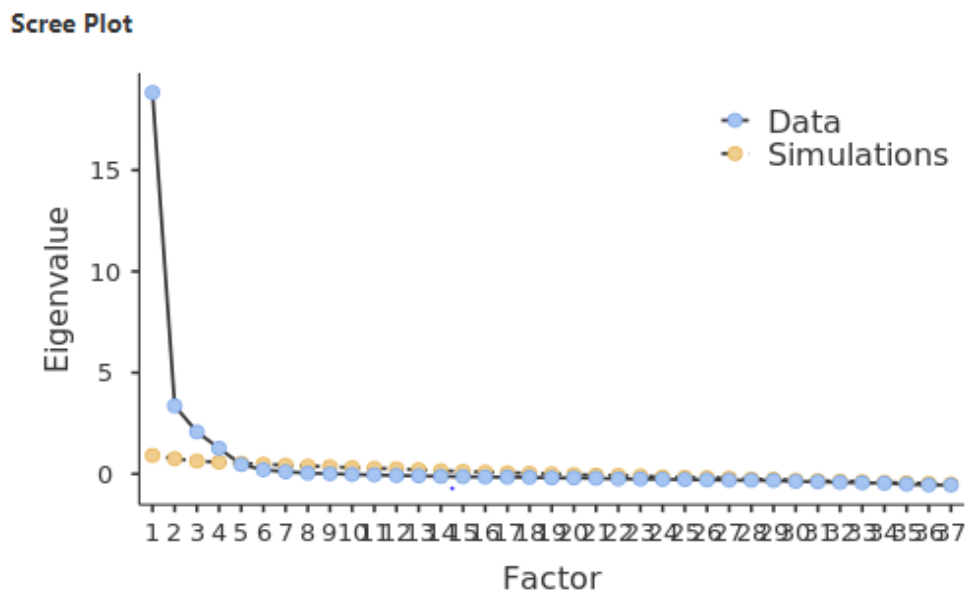

Figure 1. Exploratory Factor Analysis Output

Table 6. Items in Factors and Factor Loading Distributions

\begin{tabular}{|c|c|c|c|c|}
\hline \multirow{2}{*}{ Statements } & \multicolumn{4}{|c|}{ Factors } \\
\hline & 1 & 2 & 3 & 4 \\
\hline S41 & .827 & & & \\
\hline S43 & .810 & & & \\
\hline S40 & .783 & & & \\
\hline S38 & .781 & & & \\
\hline S46 & .774 & & & \\
\hline S44 & .757 & & & \\
\hline S19 & .747 & & & \\
\hline S39 & .726 & & & \\
\hline S56 & .697 & & & \\
\hline S42 & .675 & & & \\
\hline S45 & .555 & & & \\
\hline S53 & .554 & & & \\
\hline S8 & & .845 & & \\
\hline S5 & & .814 & & \\
\hline S9 & & .790 & & \\
\hline S2 & & .784 & & \\
\hline S6 & & .778 & & \\
\hline S3 & & .773 & & \\
\hline S1 & & .749 & & \\
\hline S7 & & .739 & & \\
\hline S4 & & .681 & & \\
\hline S10 & & .678 & & \\
\hline $\mathrm{S} 13$ & & .671 & & \\
\hline S32 & & & .799 & \\
\hline S28 & & & .774 & \\
\hline S31 & & & .773 & \\
\hline S30 & & & .752 & \\
\hline S34 & & & .725 & \\
\hline S35 & & & .684 & \\
\hline S26 & & & .683 & \\
\hline S29 & & & .554 & \\
\hline S48 & & & & .795 \\
\hline S49 & & & & .793 \\
\hline S54 & & & & .706 \\
\hline S47 & & & & .656 \\
\hline S51 & & & & .635 \\
\hline S50 & & & & .613 \\
\hline
\end{tabular}


Explanatory factor analysis results are given in Table 6. The first dimension of the scale, "Trust" consists of 12 items, the second dimension "Professional Development" consists of 11 items, the third dimension "Status" consists of 8 items, and the fourth dimension "Cooperation" consists of 6 items (see Table 7).

Table 7. Items in the Trial Form in the Dimensions

\begin{tabular}{|c|c|c|}
\hline & Dimensions & Items \\
\hline Teacher & Trust & $19-38-39-40-41-42-43-44-45-46-53-56$ \\
\hline Empowerment & Professional Development & $1-2-3-4-5-6-7-8-9-10-13$ \\
\hline \multirow[t]{2}{*}{ Scale } & Status & $26-28-29-30-31-32-34-35$ \\
\hline & Cooperation & $47-48-49-50-51-54$ \\
\hline
\end{tabular}

\subsubsection{Findings Related to Confirmatory Factor Analysis}

Exploratory factor analysis is the technique of determining how many factors can be generated with the items of the instrument and the nature of relationships among them (Seçer, 2017). An inquiry is made as to whether the indicators collected under certain factors are indicators of the theoretical structure (Green, Salkind \& Akey, 1997). The Confirmatory Factor Analysis is based on the examination of a structure determined in the exploratory factor analysis, whether it is verified or not (Seçer, 2017).

While interpreting the EFA results, it was adhered to the rule that the factor loadings that is expected to be theoretically included in any item to remain on the scale should be above .32 (Tabachnick \& Fidell, 2000). A higher standard was set for this study and items with factor loadings below .50 were excluded from the scale. In Table 8 below, the equivalents of the scale items in the trial form in the Teacher Empowerment Scale are given.

Table 8. The Equivalents of the Items in the Trial Form on the Scale

\begin{tabular}{cc|cc}
\hline Trial Form & Scale & Trial Form & Scale \\
\hline SD1 & S1 & SD35 & S20 \\
SD2 & S2 & SD38 & S21 \\
SD3 & SD39 & S22 \\
SD4 & S3 & SD40 & S23 \\
SD5 & SD41 & S24 \\
SD6 & S5 & SD42 & S25 \\
SD7 & S6 & SD43 & S26 \\
SD8 & S7 & SD44 & S27 \\
SD9 & S8 & SD45 & S28 \\
SD10 & S9 & SD46 & S29 \\
SD13 & S10 & SD47 & S30 \\
SD19 & S11 & SD48 & S31 \\
SD26 & S12 & SD49 & S32 \\
SD28 & S13 & SD50 & S33 \\
SD29 & S14 & SD51 & S34 \\
SD30 & S15 & SD53 & S35 \\
SD31 & S16 & SD54 & S36 \\
SD32 & S17 & SD56 & S37 \\
SD34 & S18 & & \\
\hline
\end{tabular}

CFA was performed to confirm the EFA results and to test the theoretically constructed measurement model. As a result of the confirmatory factor analysis, acceptable fit indices and values of the scale are given in Table 9. 
Table 9. Confirmatory Factor Analysis Values and Fit Indices

\begin{tabular}{|c|c|c|c|c|}
\hline Fit indices & Value & $\begin{array}{c}\text { The value of } \\
\text { the scale }\end{array}$ & Fitness & References \\
\hline $\mathrm{X}^{2} / \mathrm{sd}$ & Between 0 and 5 & 3.12 & Acceptable & Wheaton, Muthen, Alwin \& Summers, 1977 \\
\hline RMSEA & $\leq 0.08$ & 0.07 & Acceptable & $\begin{array}{l}\text { Hooper, Coughlan \& Mullen (2008), Sümer } \\
(2000)\end{array}$ \\
\hline GFI & Between 0.85 and 1 & 0.72 & & Andersen \& Gerbing, 1984; Cole, 1987 \\
\hline AGFI & Between 0.80 and 1 & 0.68 & & Andersen \& Gerbing, 1984; Cole, 1987 \\
\hline CFI & $\geq 0.95$ & 0.98 & Acceptable & $\begin{array}{l}\text { Hu \& Bentler (1999), Sümer (2000), } \\
\text { Tabachnick \& Fidell (2000) }\end{array}$ \\
\hline NFI & Between 0.90 and 1.00 & 0.97 & Acceptable & $\begin{array}{l}\text { Sümer (2000), Tabachnick \& Fidell (2000), } \\
\text { Thompson (2008) }\end{array}$ \\
\hline NNFI(TLI) & Between 0.90 and 1.00 & 0.98 & Acceptable & $\begin{array}{l}\text { Sümer (2000), Tabachnick \& Fidell (2000), } \\
\text { Thompson (2008) }\end{array}$ \\
\hline RMR & $\leq 0.08$ & 0.05 & Acceptable & Brown (2006), Hu \& Bentler (1999) \\
\hline SRMR & $\leq 0.08$ & 0.05 & Acceptable & Brown (2006), Hu \& Bentler (1999) \\
\hline IFI & Between 0.90 and 1.00 & 0.98 & Acceptable & Sümer (2000) \\
\hline
\end{tabular}

As a result of CFA, the structure revealed in EFA was confirmed. The model obtained with CFA is shown in Figure 2. A second-level confirmatory factor analysis was conducted in order to show that the dimensions of "professional development", "trust", "status" and "cooperation" obtained by the first-level confirmatory factor analysis of the teacher empowerment scale together represent the "teacher empowerment" variable as an upper level concept. The variances explained by the teacher empowerment variable in the first-level variables were revealed by the analysis. The factorial model of the second level CFA result and the standardized coefficients of the factor-item relationship are given in Figure 2. When the values given in Table 9 are analyzed, GFI and AGFI fit indices indicate that the data are not compatible. However, since the GFI and AGFI indices are affected by the sample size (Aybek \& Cikrikci, 2018; Bayram, 2013; Hooper, Coughlan \& Mullen, 2008; Raykov \& Marcoulides, 2006; Sharma, Mukherjeee, Kumar \& Dilor, 2005) and other fit indices are within the acceptable limits, it was concluded that the data collected in the research fit the factor structure of the scale. Since the RMSEA, CFI, NNFI (TLI), SRMR values are within the desired level ranges in the scale, it can be said that the collected data fit the factor structure of the scale.

According to the fit indices obtained, it can be said that the construct validity of the Teacher Empowerment Scale has been confirmed. The Maximum Likelihood (ML) estimation techniques have been used since the variables are measured on an interval scale and have a multivariate normal disribution. Factor loadings range from 0.73 to 0.92 in the "Trust" dimension, 0.67 to 0.93 in the "Professional Development" dimension, 0.66 to 0.90 in the "Status" dimension, and 0.83 to 0.88 in the "Cooperation" dimension.

Within the context of the compliance validity study, the correlation values of the four factors related to each other and the entire scale were examined. In order to determine the data analysis technique to be used, it was first examined whether the data showed a normal distribution. 


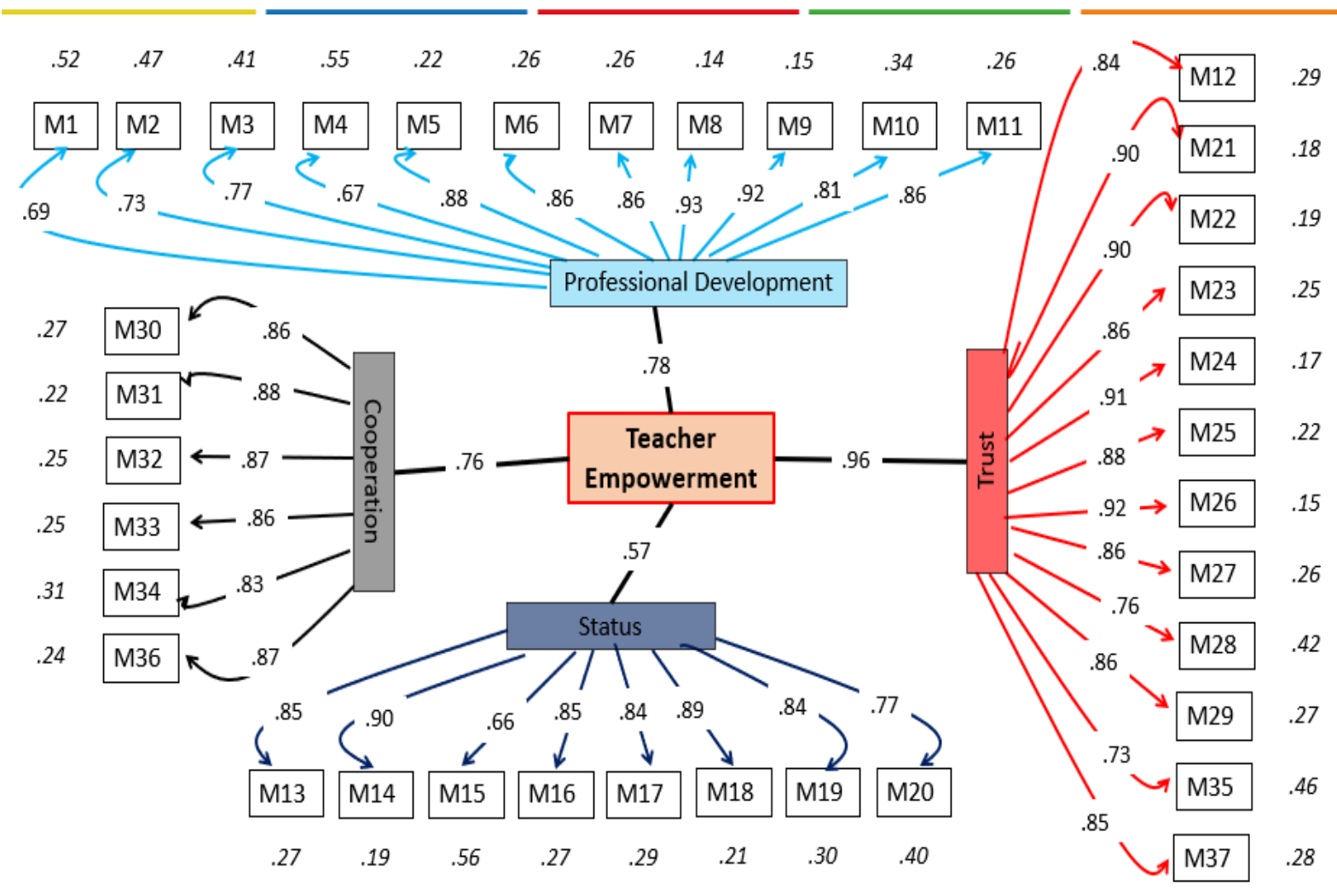

Figure 2. Measurement Model for Teacher Empowerment Scale

Factors and scale are normally distributed according to skewness and kurtosis values in Table 9. After the normality test, Pearson Correlation Analysis was performed to determine the correlation coefficients. Correlation coefficients of the four factors related to each other and the entire scale are given in Table 10. As a result of the correlation analysis, it was revealed that the factors had significant relationships with each other and with the entire scale.

Table 10. Correlation Coefficients between Factors

\begin{tabular}{lccccc}
\hline Dimensions & $\begin{array}{c}\text { Professional } \\
\text { Development }\end{array}$ & Trust & Status & Cooperation & $\begin{array}{c}\text { Teacher } \\
\text { Empowerment }\end{array}$ \\
\hline Professional & 1 & $.758^{* *}$ & $.440^{* *}$ & $.620^{* *}$ & $.861^{* *}$ \\
Development & & 1 & $.552^{* *}$ & $.763^{* *}$ & $.932^{* *}$ \\
Trust & & & 1 & $.520^{* *}$ & $.730^{* *}$ \\
Status & & & & 1 & $.828^{* *}$ \\
Cooperation & & & & & 1 \\
Teacher & & & & & \\
Empowerment & & & &
\end{tabular}

Büyüköztürk (2018) suggests that the correlation coefficient between .70-1.00 as an absolute value is high, that between .30 and .70 is medium, and between .00 and .30 indicates a low level of relationship. Total teacher empowerment score was found to be highly correlated with all dimensions of the scale. When the relations between the dimensions were examined, it was found that the "professional development" dimension was highly related to the "trust" dimension and a moderately related to "status" and "cooperation" dimensions. In addition, it was found that the "trust" dimension has a moderate relationship with the "status" dimension, a high level relationship with the "cooperation" dimension. Finally, it was found that the "status dimension" had a moderate relationship with the "cooperation" dimension. 
Item total correlations were examined in order to achieve item analysis of the Teacher Empowerment Scale. Item total correlations should be greater than .30. Because Field (2005) stated that if the item total correlations were less than .30, that item did not measure the same structure as the other items, meaning that the item showed a weak correlation with the rest of the scale. The mean, standard deviation and item total correlations of the scale are given in Table 11.

Table 11. Item-Total Statistics

\begin{tabular}{cccc|cccc}
\hline Item No & $\bar{x}$ & $d f$ & $\begin{array}{c}\text { Item-Total } \\
\text { Correlations }\end{array}$ & Item no & $\bar{x}$ & $d f$ & $\begin{array}{c}\text { Item-Total } \\
\text { Correlations }\end{array}$ \\
\hline S1 & 4.43 & .795 & .628 & $S 20$ & 3.27 & .967 & .637 \\
$S 2$ & 4.42 & .779 & .640 & $S 21$ & 4.01 & .971 & .837 \\
$S 3$ & 4.24 & .896 & .720 & $S 22$ & 4.01 & .948 & .866 \\
$S 4$ & 3.61 & 1.070 & .568 & $S 23$ & 3.63 & 1.133 & .783 \\
S5 & 4.13 & .967 & .750 & $S 24$ & 4.02 & .952 & .816 \\
S6 & 3.97 & 1.026 & .706 & $S 25$ & 4.04 & .965 & .803 \\
S7 & 3.93 & 1.053 & .732 & $S 26$ & 4.07 & .915 & .851 \\
S8 & 4.09 & .954 & .787 & $S 27$ & 3.63 & 1.122 & .802 \\
$S 9$ & 4.06 & .964 & .803 & $S 28$ & 3.70 & 1.054 & .770 \\
S10 & 3.86 & 1.052 & .728 & $S 29$ & 3.63 & 1.119 & .779 \\
S11 & 3.79 & 1.057 & .779 & $S 30$ & 3.80 & .934 & .704 \\
S12 & 4.03 & .990 & .797 & $S 31$ & 3.69 & .996 & .738 \\
S13 & 3.08 & 1.244 & .598 & $S 32$ & 3.76 & .908 & .769 \\
S14 & 3.11 & 1.103 & .629 & $S 33$ & 3.44 & 1.023 & .715 \\
S15 & 3.68 & 1.010 & .567 & $S 34$ & 3.76 & .908 & .648 \\
S16 & 3.17 & 1.111 & .571 & $S 35$ & 3.44 & 1.023 & .717 \\
S17 & 3.49 & 1.103 & .606 & $S 36$ & 3.91 & .855 & .766 \\
S18 & 3.21 & 1.120 & .591 & $S 37$ & 3.96 & .965 & .811 \\
S19 & 3.30 & .984 & .619 & & & & \\
\hline
\end{tabular}

If item discrimination index values are above .30 , it means that item discrimination is very good (Büyüköztürk, Çakmak, Akgün, Karadeniz \& Demirel, 2010; Crocker \& Algina, 1986). Accordingly, it can be said that the Teacher Empowerment Scale consists of items with high discrimination.

\subsubsection{Findings Related to Reliability}

Cronbach's Alpha and Omega Reliability methods were used to determine reliability levels in the study. Büyüköztürk (2006); Erkuş (2014); Field (2005); Fornell and Larcker (1981); Nunnaly and Bernstein (1994); Karagöz (2016) and Seçer (2017) stated that the scale will be accepted as reliable when the Cronbach Alpha value is .70 and above. In the context of internal consistency, Cronbach Alpha analysis is not considered sufficient in case of multiple factor structures. It is also recommended to calculate the Omega Reliability coefficient (Dunn, Baguley \& Brunsden, 2014). The results related to the reliability analysis of the scale are given in Table 12.

Table 12. Reliability Values of Teacher Empowerment Scale

\begin{tabular}{lcc}
\hline Dimensions & Cronbach's Alpha & McDonald's Omega \\
\hline Professional Development & .956 & .957 \\
Trust & .970 & .971 \\
Status & .944 & .945 \\
Cooperation & .946 & .946 \\
Total Scale & .973 & .974 \\
\hline
\end{tabular}


Reliability values for the dimensions of the scale and the total scale were calculated using the Jamovi program. It is also recommended to calculate the Omega Reliability coefficient (Dunn, Baguley \& Brunsden, 2014). The total McDonald's $\omega$ value of the scale was calculated as 0.974 (with the Jamovi program), and the cronbach's alpha value was calculated as 0.973 . The reliability of the dimensions of the scale is McDonald's $\omega$ value $=0.957$ for professional development dimension, Cronbach's alpha value is 0.956 ; McDonald's $\omega$ value for the trust dimension $=0.971$, Cronbach's alpha value is 0.970 ; McDonald's $\omega$ value for the status dimension was calculated as 0.945 , the Cronbach's alpha value as 0.944 , and for the cooperation dimension as 0.946 , the cronbach's alpha value was calculated as 0.946 . It can be interpreted that the omega coefficient is more reliable than the alpha coefficient, and according to these results, the reliability of the whole scale and all four sub-dimensions is high (Peters, 2014).

\subsubsection{Evaluation of Scores from the Teacher Empowerment Scale}

There are 37 items in the Teacher Empowerment Scale (see A1 Table 1). 5-point Likert type was used in the scale such as "I strongly disagree (1), I disagree (2), I partially agree (3), I agree (4), I strongly agree (5)". The scale is four-dimensional: "professional development, trust, status and cooperation". There are no inverse items in the scale. "Professional Development" dimension should be minimum 12, maximum 60; "Trust" dimension is minimum 11 and maximum 55; Minimum 8 and maximum 40 in "status" dimension; Minimum 6 and maximum 30 points can be obtained in the "cooperation" dimension. A total score can be obtained from the entire scale. The increase in the scores obtained from the Teacher Empowerment Scale means that teachers' perceptions about empowerment are at a high level.

For the convergent validity of the scale, the analysis of the Average Variance Extracted (AVE) values of each factor was determined by comparing the correlation of each factor with each other (see Table 13; Fornell \& Larcker, 1981). Discriminant validity was evaluated by comparing the square root value of the variance explained with the square of correlations between factors. Convergent and distinctive validity is another type of validity used in testing and verifying the established model (Fornell \& Larcker, 1981; Malhotra, 2011). Convergent validity of the measurement model can be evaluated with Average Variance Extracted (AVE) and Combined Reliability (CR). Acceptable value of CR and AVE is 0.70 (Fornell \& Larcker, 1981) and value of AVE and CR of this scale is above 0.70. Also, the CR value should be greater than the AVE value (Gouveia \& Soares, 2015; Raykov, 1997). AVE and CR values are presented in Table 13. CR and AVE values were calculated using the Excel program. In this study, CR value was calculated as 0.999 , AVE value as 0.948 . When CR and AVE values of dimensions are examined, it was calculated as $\mathrm{CR}=0.999$ and $\mathrm{AVE}=0.948$ for professional development; $\mathrm{CR}=0.996$ and $\mathrm{AVE}=0.949$ for trust; $\mathrm{CR}=0.994$ and $\mathrm{AVE}=0.946$ for status; $\mathrm{CR}=0.990$ and $\mathrm{AVE}=0.944$ for cooperation. It is seen that the entire scale and dimensions have $\mathrm{CR}$ and AVE values over 0.70 . Therefore, it can be said that discriminant validity and convergent validity are provided. All these findings show that the data obtained are compatible with the structure revealed by EFA.

Table 13. CR and AVE values

\begin{tabular}{lcc}
\hline Dimensions & $C R$ & $A V E$ \\
\hline Professional Development & .999 & .948 \\
Trust & .996 & .949 \\
Status & .994 & .946 \\
Cooperation & .990 & .944 \\
Total Scale & .999 & .948 \\
\hline
\end{tabular}




\section{DISCUSSION and CONCLUSION}

When the national and international literature on teacher empowerment is examined, no scale was found to directly determine the perceptions of teachers about empowerment levels. This research is thought to be important in terms of filling this gap in the literature. With this research, a valid and reliable measurement tool for teacher empowerment was tried to be developed. While preparing the teacher empowerment scale, opinions of the teachers were taken first, codes and categories were determined in line with these opinions, and scale items were written in line with the literature for these codes and categories. Scale items were submitted to expert opinions to ensure scope and appearance validity. In line with the opinions of experts, arrangements were made in the item content, dimensions and expressions and two items were added to the scale. Thus, a draft measuring tool with 62 items was obtained. The items in the scale were applied to sample 1.

EFA and CFA were used to test the construct validity of the teacher empowerment scale. As a result of the EFA, a four-factor structure consisting of 37 items explaining approximately $70 \%$ of the total variance was obtained. The first factor was named as "professional development", the second factor as "trust", the third factor as "status" and the fourth factor as "cooperation" considering the item contents and theoretical structure collected in the factors. CFA was conducted to determine whether the theoretically designed model was verified by the data. The data obtained from the CFA showed that the fit indices of the four-factor structure related to teacher empowerment were sufficient.

The reliability of the measurements obtained from the teacher empowerment scale was examined by Cronbach Alpha and Omega Reliability methods. Cronbach Alpha reliability of the measurements was calculated as .956 in professional development dimension, .970 in trust dimension, .944 in status dimension and .946 in collaboration dimension. The total reliability of the scale is .973 . Measurements with a reliability coefficient of .70 and above are considered reliable (Büyüköztürk, 2006; Durmuş, Yurtkoru \& Zinc, 2016; Field, 2005; Fornell and Larcker, 1981; Karagöz, 2016; Nunnaly \& Bernstein, 1994; Seçer, 2017 and Tezbaşaran, 1997). Omega reliability of the measurements was calculated as .957 in professional development dimension, .971 in trust dimension, .945 in status dimension and .946 in collaboration dimension. The total reliability of the scale is .974 . Item analysis was conducted in order to determine the total score predictive power of the items in the teacher empowerment scale and to determine the discrimination levels. Within the scope of item analysis, the corrected item total correlations were examined. CR and AVE values were calculated using the Excel program. In this study, Combined Reliability (CR) value was calculated as 0.999, Average Variance Extracted (AVE) value as 0.948. Therefore, it can be said that discriminant validity and convergent validity are provided. When CR and AVE values of dimensions are examined, it was calculated as $\mathrm{CR}=0.999$ and $\mathrm{AVE}=0.948$ for professional development; $\mathrm{CR}=0.996$ and $\mathrm{AVE}=0.949$ for trust; $\mathrm{CR}=0.994$ and $\mathrm{AVE}=0.946$ for status; $\mathrm{CR}=0.990$ and $\mathrm{AVE}=0.944$ for cooperation. It can be said that discriminant validity and convergent validity are provided.

It is suggested that researches should be carried out to reveal the existing situation regarding the empowerment of teachers, to determine which variables affect the teacher empowerment and from which variables teacher empowerment is affected. Conducting researches in which teacher empowerment scale will be used is important in terms of contributing to the scale's measuring power and intended use.

\section{Declaration of Conflicting Interests and Ethics}

The authors declare no conflict of interest. This research study complies with research publishing ethics. The scientific and legal responsibility for manuscripts published in IJATE belongs to the author(s). 


\section{ORCID}

Yeliz ÖZKAN HIDIROĞLU (D) https://orcid.org/0000-0002-5176-1235

Abdurrahman TANRIÖĞEN (iD) https://orcid.org/0000-0002-5491-3273

\section{REFERENCES}

Abbott, M. L. (2011). Understanding educational statistics using Microsoft Excel and SPSS. United States: John Wiley \& Sons, Inc.

Acquaah, M. (2004). Human factor theory, organizational citizenship behaviors and human resources management practices: An integration of theoretical constructs and suggestions for measuring the human factor. Review of Human Factor Studies Special Edition, 10(1), 118-151.

Addi-Raccah, A. (2009). Between teacher' empowerment and supervision: A comparison of school leaders in the 1990s and the 2000s. Management in Education, 23(4), 161-167.

Al-Yaseen W. S., \& Al-Musaileem M. Y. (2015) Teacher empowerment as an important component of job satisfaction: a comparative study of teachers' perspectives in AlFarwaniya District, Kuwait, Compare. A Journal of Comparative and International Education, 45(6), 863-885.

Altınkurt, Y., Türkkaş Anasız, B., \& Ergin Ekinci, C. (2016). Öğretmenlerin yapısal ve psikolojik güçlendirilmeleri ile örgütsel vatandaşlık davranıșları arasındaki ilișki. Ĕ̌gitim ve Bilim, 41(187), 79-96.

Anderson, J. C. \& Gerbing, D. W. (1984). The effect of sampling error on convergence, improper solutions, and goodness-of-fit indices for maximum likelihood confirmatory factor analysis. Psychometrika, 49(2), 155-173.

Aybek, E. C., \& Çıkrıkçı, R. N. (2018). Kendini değerlendirme envanterinin bilgisayar ortamında bireye uyarlanmış test olarak uygulanabilirliği, [Applicability of the self assessment inventory as a computerized adaptive test]. Türk Psikolojik Danışma ve Rehberlik Dergisi, 8(50), 117-141.

Bayram, N. (2013). Yapısal eşitlik modellemesine giriş AMOS uygulamaları, 2. edition. İstanbul: Ezgi Kitabevi.

Bogler, R., \& Nir, A. E. (2012). The importance bof teachers percieved organizational support to job satisfaction: What empowerment got to do it. Journal of Education Administration, 5(3), 287-306.

Bogler, R., \& Somech, A. (2004). Influence of teacher empowerment on teacher's organizational commitment, professional commitment and organizational citizenship behavior in schools. Teaching and Teacher Education, 20, 277-289.

Brown T. A. (2006) Confirmatory factor analysis for applied research. Guilford, New York.

Büyüköztürk, Ş. (2018). Sosyal bilimler için veri analizi el kitabı, [Data analysis handbook for social sciences]. Ankara: Pegem Akademi.

Büyüköztürk, Ş., Çakmak, E., Akgün, Ö. E., Karadeniz, Ş., \& Demirel, F. (2010). Bilimsel araştırma yöntemleri (5th edition). Ankara: PegemA Yayınc1lık.

Cattell, R. B. (1978). The scientific use of factor analysis. New York: Plenum.

Cole, D. A. (1987). Utility of confirmatory factor analysis in test validation research. Journal of Consulting and Clinical Psychology, 55, 1019-1031.

Comrey, A.L. ve Lee, H.B. (1992) A first course in factor analysis. Hillsdale, NJ: Erlbaum. 1992, 22-24.

Crocker, L. \& Algina, J. (1986). Introduction to classical and modern test theory. Orlando: Harcourt Brace Jovanovich Inc.

Çokluk, Ö., Şekercioğlu, G., \& Büyüköztürk, Ş. (2016). Sosyal bilimler için çok değişkenli istatistik SPSS ve LISREL Uygulamalar, 4th edition. Ankara: Pegem Akademi. 
Darren, G., \& Mallery P, 2016, IBM SPSS Statistics 23 step by step a simple guide and reference, 14th edition. New York: Routledge.

Dee, J.R., Henkin, A.B., \& Duemer, L. (2003). Structural antecedents and psychological correlates of teacher empowerment. Journal of Educational Administration, 41(3), 25777.

Demir, E., Saatçioğlu, Ö., \& İmrol, F. (2016). Uluslararası dergilerde yayımlanan eğitim araştırmalarının normallik varsayımları açısından incelenmesi. Current Research in Education, 2(3), 130-148.

DeVellis, R. F. (2003). Scale development: Theory and applications (Vol. 26). Thousand Oaks, California: Sage.

Durmuş, B., Yurtkoru, E.S., \& Çinko, M. (2016). Sosyal bilimlerde Spss'le veri analizi. İstanbul: Beta.

Erkuş, A. (2014). Psikolojide Ölçme ve Ölçek Geliştirme - I Temel Kavramlar ve İşlemler (2.Basım). Ankara: Pegem Akademi.

Fandiño, Y. J. (2010). Research as a means of empowering teachers in the 21 st century. Retrieved from http://educacionyeducadores.unisabana.edu.co/index.php/eye/article/vie $\mathrm{w} / 1624 / 2134$

Field, A. (2005). Discovering statistics using SPSS, 2nd edition. London: Sage Publication.

Firestone, W. A, \& Pennell, J. R. (1993). Teacher commitment, working conditions, and differential incentive policies. Review of Educational Research, 63(4), 489-525.

Fornell, C., \& Larcker D. (1981). Evaluating structural equation models with unobservable variables and measurement error. Journal of Marketing Research, 18(1), 39-50.

Gouveia, V. V., \& Soares, A. K. S. (2015). Calculadoras de validade de construto (CVC). João Pessoa, PB: BNCS/ Universidade Federal da Paraíba, [Construct Validity Calculators (CVC)] Retrieved from http://akssoares.com/psicometria/calculadora-vmee-cc

Green, S. B., Salkind, N. J., \& Akey, T. M. (1997). Using SPSS for windows: Analyzing and understanding data. NJ: Prentice Hall, Inc.

Henson, R. K., \& Roberts, J. K. (2006). Use of exploratory factor analysis in published research: common errors and some comment on improved practice. Educational and Psychological Measurement, 66(3), 393-416.

Hooper, D., Coughlan, J., \& Mullen, M. (2008). Structural equation modelling: Guidelines for determining model fit. Electronic Journal of Business Research Methods, 6(1), 53-60.

Hu, L. T., \& Bentler, P. M. (1999). Cutoff criteria for fit indexes in covariance structure analysis: Conventional criteria versus new alternatives. Structural Equation Modeling: A Multidisciplinary Journal. 6(1), 1-55.

Jiang, Y., Li, P., Wang, J., \& Li, H. (2019). Relationships between kindergarten teachers' empowerment, job satisfaction, and organizational climate: A Chinese model. Journal of Research in Childhood Education, 33(2), 257-270.

Kanter, R. (1993). Women and men of the corporation, 2nd edition. New York: Basic Books.

Karagöz, Y. (2016). SPSS ve AMOS 23 uygulamall istatistiksel analizler. Ankara: Nobel Yayıncilik.

Kass, R. A., \& Tinsley, H. E. A. (1979). Factor analysis. Journal of Leisure Research, 11, 120138.

Lichenstein, G., McLaughlin, M., \& J. Knudsen. (1991). Teacher empowerment and professional knowledge. CPRE research report series. New Brunswick, NJ: Consortium for Policy Research in Education.

Lieberman, A., \& Miller, L. (1990), Restructuring schools: What matters and what works. Phi Delta Kappan, 71(10), 759-764.

Lightfoot, S. (1986). On goodness of schools: Themes of empowerment. Peabody Journal of Education, 63(3), 9-28. 
Lintner, J. D. (2008). The relationship between perceived teacher empowerment and principal use of power. Auburn University. ProQuest Dissertations and Theses, Retrieved from http://search.proquest.com/docview/89141781?accountid=15099

Maeroff, G. (1988). The empowerment of teachers: Overcoming the crisis of confidence. New York: Teachers College Press.

Malhotra, N. K. (2011). Pesquisa de marketing: uma orientação aplicada, (6th ed.) São Paulo: Bookman.

Morales-Thomas, M. (2015). Practices that promote parent engagement in an urban elementary school: A phenomenological study of Latino parents of English language learners (Doctoral dissertation). Available from ProQuest Dissertations and Theses database. (UMI No. 3685358).

Morris, V., \& Nunnery, J. (1993). Teacher empowerment in a professional development school collaborative: Pilot assessment. technical report 931101. Memphis, TN: Center for Research in Educational Policy, College of Education, Memphis State University.

Nunnaly, J., \& Bernstein, I. (1994). Psychometric theory. New York: McGraw-Hill.

Ökmen, A. (2018). Öğretmen güçlendirmeye ilişkin lisede görev yapan ögrretmenlerin algıları, [The perceptions of high school teachers regarding teacher empowerment], Unpublished Master Thesis, Yıldız Teknik University, Social Sciences Institute, Istanbul.

Peters, G. J. Y. (2014). The alpha and the omega of scale reliability and validity: Why and how to abandon Cronbach's alpha and the route towards more comprehensive assessment of scale quality. European Health Psychologist, 16(2), 56-69.

Rappaport, J. (1985). The power of empowerment language. Social Policy, 16, 15-21.

Raykov, T. (1997). Estimation of composite reliability for congeneric measures. Applied Psychological Measurement, 21(2), 173-184.

Raykov, T., \& Marcoulides, G.A. (2006). A first course in structural equation modeling, 2nd edition. Mahlah, New Jersey, London: Lawrence Erlbaum Associates.

Rice, E.M., \& Schneider, G. T. (1994). A Decade of teacher empowerment: An empirical analysis of teacher involvement in decision making, 1980-1991. Journal of Educational Administration, 32(1), 43-58.

Rinehart, J., \& Short, P. (1994). Job satisfaction and empowerment among teacher leaders, reading recovery teachers, and regular classroom teachers. Education, 114(4), 570-580.

Sahin. M. D., \& Aybek, E. C. (2019). Jamovi: An easy to use statistical software for the social scientists. International Journal of Assessment Tools in Education, 6(4), 670-692.

Seçer, İ. (2017). SPSS ve LISREL ile pratik veri analizi analiz ve raporlaştırma. Ankara: Anı Yayınc1lik.

Sharma, A. (2008) Logics of empowerment: Development, gender and governance in Neoliberal India. Minneapolis: U of Minnesota P.

Sharma, S., Mukherjee, S., Kumar, A., \& Dillon, W. R. (2005). A simulation study to investigate the use of cutoff values for assessing model fit in covariance structure models. Journal of Business Research, 58(7), 935- 943.

Sharp, D.C. (2009). A study of the relationship between teacher empowerment and principal effectiveness. (Unpublished doctoral dissertation). Baker University, Faculty of Education, USA.

Short, P. (1991). Teacher commitment and job satisfaction: Which comes first? Paper presented at the Annual Meeting of American Educational Research Association, Chicago, IL, April.

Short, P. M., \& Rinehart, J. S. (1992). School participant empowerment scale: Assessment of level of empowerment within the school environment. Educational and Psychological Measurement, 52(6), 951-960.

Sizer, T. (1992). Horace's school. Boston, MA: Houghton, Miffin. 
Somech, A. (2005). Teachers' personal and team empowerment and their relations to organizational outcomes: Contradictory or compatible constructs?. Educational Administration Quarterly, 41(2), 237-266.

Sprague, J. 1992. Critical perspectives on teacher empowerment. Communication in Education, 41 (2), 181-203.

Spreitzer, G. (1995). Psychological empowerment in the workplace: Dimensions, measurement and validation. Academy of Management Journal, 38(5), 1442-1465.

Squire-Kelly, V. D. (2012). The relationship between teacher empowerment and student achievement. (Unpublished PhD Dissertation). Georgia Southern University.

Sümer, N. (2000). Yapısal eșitlik modelleri: Temel kavramlar ve örnek uygulamalar. Turkish Psychological Articles, 3(6), 49-74.

Şencan, H. (2005). Sosyal ve davranışsal ölçümlerde güvenirlik ve geçerlik (Reliability and validity in social and behavioural measurements). Ankara: Seçkin.

Tabachnick, B. G., \& Fidell, L. S. (2000). Using multivariate statistics (4th edition). New York, NY: Harper \& Row.

Tezbaşaran, A. A. (1997). Likert tipi ölçek geliştirme kılavuzu. Ankara: Türk Psikologlar Derneği.

Thompson, B. (2008). Exploratory and confirmatory factor analysis: Understanding concepts and applications. 3rd edition. Washington, DC: American Psychological Association.

Watts, D. M. (2009). Enabling school structure, mindfulness, and teacher empowerment: test of a theory (Unpublished doctoral dissertation). Retrieved from ProQuest Dissertations and Thesis database.

Wheaton, B., Muthen, B., Alwin, D. F., \& Summers, G. F. (1977). Assessing reliability and stability in panel models. Sociological Methodology, 8, 84-136.

Wilson, S., \& Coolican, M. J. (1996). Howhigh and lowself-empowered teacherswork with colleagues and school principals. Journal of Educational Thought, 30, 99-118.

Veisi, S., Azizifar, A., Gowhary, H., \& Jamalinesari, A. (2015). The relationship between iranian efl teachers' empowerment and teachers' self-efficacy. Procedia - Social and Behavioral Sciences, 185(13), 437-445.

Yıldırım, A., \& Şimşek, H. (2005). Sosyal bilimlerde nitel araştırma yöntemleri. Ankara: Seçkin Yayınları.

Yin, H. B., Jin, Y. L., \& Lee, C. K. (2009). The impact of trust and empowerment culture on curriculum reform. Journal of Capital Normal University, 1, 125-132.

Yurdabakan, I., \& Cum, S. (2017). Scale development in behavioral sciences (Based on exploratory factor analysis). Turkish Journal of Family Medicine \& Primary Care, 11, 108-126.

Zimmerman, M. A. (2000). Empowerment theory: Psychological, organizational and community levels of analysis. In J. Rappaport \& E. Seidman (Eds.), Handbook of community psychology (pp. 43-63). New York: Kluwer Academic/Plenum. 


\section{APPENDIX}

A1 Table 1. Teacher Empowerment Scale

\begin{tabular}{|c|c|c|}
\hline Dimension & $\begin{array}{c}\text { Item } \\
\text { No }\end{array}$ & English Form \\
\hline \multirow{11}{*}{$\begin{array}{l}\text { Professional } \\
\text { Development }\end{array}$} & I 01 & $\begin{array}{l}\text { Participation in seminars/conferences of important people in my profession is not } \\
\text { prevented by the school administration. }\end{array}$ \\
\hline & I 02 & $\begin{array}{l}\text { It is not prevented by the school administration to participate in any kind of } \\
\text { training related to my branch, }\end{array}$ \\
\hline & I 03 & $\begin{array}{l}\text { Attending personel development courses (drama, diction, personel development, } \\
\text { effective communication, etc.) is supported by the school management. }\end{array}$ \\
\hline & I 04 & $\begin{array}{l}\text { I have the chance to receive trainings about immigrant or problem students by the } \\
\text { school administration. }\end{array}$ \\
\hline & I 05 & $\begin{array}{l}\text { It is supported by the school administration to receive training on educational } \\
\text { technology. }\end{array}$ \\
\hline & I 06 & $\begin{array}{l}\text { I have the chance to receive trainings on new teaching methods and techniques by } \\
\text { the school administration. }\end{array}$ \\
\hline & I 07 & $\begin{array}{l}\text { I have the chance to participate in in-service trainings frequently and regularly by } \\
\text { the school administration. }\end{array}$ \\
\hline & I 08 & $\begin{array}{l}\text { It is supported by the school administration to participate in scientific training in } \\
\text { my environment. }\end{array}$ \\
\hline & I 09 & $\begin{array}{l}\text { It is supported by the school administration to receive trainings on classroom } \\
\text { management. }\end{array}$ \\
\hline & I 10 & $\begin{array}{l}\text { I have chance to participate in training (legislative training) where my Powers } \\
\text { and rights are taught. }\end{array}$ \\
\hline & I 11 & $\begin{array}{l}\text { The school administration provides me wqith an environment to attend the } \\
\text { courses and trainings I need. }\end{array}$ \\
\hline \multirow{12}{*}{ Trust } & I 12 & I feel that my administrators value me a a teacher. \\
\hline & I 21 & My administrators have understanding towards me. \\
\hline & I 22 & My administrators are supportive of my profession. \\
\hline & I 23 & My administrators behave fairly within the school. \\
\hline & I 24 & I have a healty dialogue with my administrators. \\
\hline & I 25 & My administrators contact me individually when there is a problem. \\
\hline & I 26 & My administrators respect me. \\
\hline & I 27 & My administrators apply school rules in the same way to everyone. \\
\hline & I 28 & I feel free while carrying out my duties. \\
\hline & I 29 & My administrators treat me empathically. \\
\hline & I 35 & Our administrators do not let our time g oto waste with unnecessary works. \\
\hline & I 37 & My administrators give me the opportunity to say my thoughts. \\
\hline \multirow{8}{*}{ Status } & I 13 & I think I have a profession with a high social status. \\
\hline & I 14 & $\begin{array}{l}\text { The teaching profession provides me with the social status I desire in my } \\
\text { environment. }\end{array}$ \\
\hline & I 15 & Teaching makes it possible for me to deal with many cultural issues.. \\
\hline & I 16 & The attitudes of people around me towards teachers make me strong. \\
\hline & I 17 & The teaching profession gives me confidence. \\
\hline & I 18 & The teaching profession gives me dignity. \\
\hline & I 19 & People around me respect the teaching profession. \\
\hline & I 20 & Teachers are well accepted by people in this area. \\
\hline \multirow{6}{*}{ Cooperation } & I 30 & $\begin{array}{l}\text { The teachers in our school cooperate with each other in linewith their } \\
\text { Professional goals. }\end{array}$ \\
\hline & I 31 & Our school has a teaching staff to work with pleasure. \\
\hline & I 32 & The cooperation of the teachers in our school makes me feel safe. \\
\hline & I 33 & Other teachers at our school appreciate my work. \\
\hline & I 34 & I think that the teacher I work with have Professional ethics. \\
\hline & I 36 & I have a chance to cooperate with other teachers at my school. \\
\hline
\end{tabular}

